\title{
The Analysis of Implementation of Specific and Sensitive Nutritional Intervention Programs in Reducing Stunting Toddler in Langkat District 2018
}

\author{
Risma Oktoria Purba ${ }^{1}$, Albiner Siagian², Destanul Aulia ${ }^{3}$ \\ 1,2,3 Departement of Administration and Health Policy, Universitas Sumatera Utara, Indonesia \\ ryzma_blackshine@yahoo.com
}

\begin{abstract}
There are five districts with the highest stunting rate in North Sumatra and in Langkat district by 38.7 percent in 2017. This research looks at the analysis of the implementation of specific and sensitive nutrition intervention programs to reduce stunting rates in langkat. This research is a qualitative study with a phenomological design using purposive sampling method with 8 informants with the criteria of program implementers and field implementers and the community using CFIR tools to see the implementation of specific and sensitive nutrition intervention programs to reduce stunting in toddlers in Langkat. From the analysis of 31 CFIR constructs, there are 6 strong constructs of influence, where 4 constructs have a positive effect, namely the characteristics of the agency structure, pressure to change, selfconfidence, program adoption and 2 constructs have a negative effect, namely external networks and external needs and incentives. There are 4 constructs that have a weak but very impactful effect where 3 constructs have a negative effect, namely the impact and desired change, the involvement of the leader and available resources and 1 construction has a positive effect, namely the level of individual change on the reduction of stunting rates in children under five in Langkat. However, improvements are needed in terms of cooperation between agencies, budgeting, additional special programs outside the specific and sensitive nutrition intervention program, the appointment of a special program leader and support for facilities, infrastructure and human resources for the implementation of the specific and sensitive nutrition intervention program in Langkat district.
\end{abstract}

Keywords

stunting, Consolidated Framework for Implementation Research (CRR); specific and sensitive nutrition interventions, implementation research

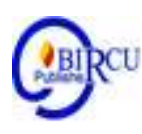

\section{Introduction}

Health is a very important element of the quality of life in national development. The national health system has established that the goal of health development is to increase awareness, willingness, and ability to live healthy for everyone so that a high degree of public health can be realized - high human resources, as an investment for socially and economically productive development (Health Law No. 36 of 2009). In realizing the optimal health degree, the role of prime health service is needed. Health care is one of the determinants of the degree of public health. One of the targets is the Public Health Center. It is a functional unit which is a center of community health development that also fosters community participation and provides comprehensive and integrated services to the community in its working area in the form of main activities. Public Health Center have the authority and responsibility for maintaining public health in their working area (MOH in Hasibuan, 2020). 
According to the Health Data and Information Window Bulletin (Sakti, Eka Satriani, 2018) stunting is a major nutritional problem facing Indonesia. Stunting itself is a condition of children having a length or height that is less when compared to age. In another section (Trihono, 2015) states that the stunting condition can be measured based on Zscore values $\geq$ 3 to <-2 SD (short) and <-3 SD (very short) according to WHO (World Health Organization) standards. Stunting can also be interpreted as a condition of failure to thrive in children under five due to chronic malnutrition, especially in the First 1000 Days of Life (HPK). In another part of the stunting rate in Indonesia, based on basic health research data (Balitbang Kemenkes RI, 2018) in 2013, there were $37.2 \%$ of children under five who experienced stunting and decreased in 2018 to $30.8 \%$, amounting to $6.4 \%$. This figure ranks Indonesia 108th out of 132 countries included in countries with high stunting rates according to data from the 2016 Global Nutrition Report. (Shinta, 2020)

The prevalence of stunting in Indonesia stood at 35.6 percent in 2010 and increased in 2013 to 37.2 percent and increased from 2010 in $35.6 \%$. There are 20 provinces that numbers of stunting above of national numbers and hard category (30-39\%) and there are 14 provinces in serious category $(>40 \%)$. Fifteen province are papua, maluku, south sulawesi, North maluku, middle sulawesi, middle kalimantan, aceh, north sumatera, southeast sulawesi, lampung, south kalimantan, west papua, west nusa tenggara, north sulawesi, east nusa tenggara (Riskesdas 2013).

North sumatera in serious category $(37,2 \%)$ and there are five higest district with numbers of stunting: Langkat (55\%), Padang Lawas (54,9\%), North Nias (54,8\%), Batubara $(54,7 \%)$, pakpak bharat $(52,3 \%)$.

Government has program that call spesific and sensitive nutrition intervention to decreasing numbers of stunting. These programs devide in two parts, first spesific nutrition intervention that is public health service in this case health service district langkat. This sector give $30 \%$ to decreasing number of stunting if the program doing well and the second is sensitive nutrition intervention, those are lintassektor office and give $70 \%$ to decreasing number of stunting.

The program of spesific nutrition intervention is Complementary food ASI, administration of worm medicine, administration for zink suplementation, full immunization, prevention and treatment of diarrhea, prevention of dengue and malaria.

The program of sensitif nutrition intervention are doing out of health service for example in food security agency, sanitation and environment, service for women and children empowerment. The programs are access to sanitation and clean water, improve food and nutrition security, provide guarantees to the poor (TNP2K).

Numbers of stunting in langkat is the highest one although have done the program spesific and sensitive nutrition intervention in community, so that it necessary to see what factors that influence the implementation of that program to decreasing numbers of stunting inn toodler in langkat in 2018.

\section{Research Method}

This is a qualitative research and use implementation research as a strategic to collect all data then it deep analyzed to seeing what factors that influence implmenetation of program spesific and sensitive nutrition intervention to decreasing numbers of stunting toddler in langkat. 
Table 1. Qualitative Use Implementation Research

\begin{tabular}{|c|c|c|c|c|c|}
\hline Domain & construction & $\begin{array}{c}\text { Inf 1/ } \\
\text { Nutrition }\end{array}$ & $\begin{array}{l}\text { Inf 2/ } \\
\text { Family } \\
\text { Health }\end{array}$ & $\begin{array}{l}\text { Inf 3/ } \\
\text { Village } \\
\text { Midwf }\end{array}$ & $\begin{array}{c}\text { Inf } 4 / \\
\text { Head of } \\
\text { HC }\end{array}$ \\
\hline Outer Setting & Patient Need & +1 & +2 & 0 & +2 \\
\hline \multirow{5}{*}{ Inner Setting } & Tension for change & +1 & +1 & 0 & 0 \\
\hline & Compatibility & +2 & +2 & +2 & +2 \\
\hline & Incentive and reward & -1 & -1 & +1 & +1 \\
\hline & Goals and feedback & +1 & +1 & +1 & +1 \\
\hline & Leadership engagement & +2 & +1 & +1 & +2 \\
\hline $\begin{array}{l}\text { Characteristic } \\
\text { of Individual }\end{array}$ & $\begin{array}{l}\text { Individual stage of } \\
\text { change }\end{array}$ & -1 & -1 & 0 & +1 \\
\hline \multirow[t]{2}{*}{ Proccess } & $\begin{array}{l}\text { Internal implementation } \\
\text { leaders }\end{array}$ & 0 & 0 & 0 & 0 \\
\hline & External change agent & +1 & 0 & 0 & +1 \\
\hline
\end{tabular}

This qualitative use implementation research done not only see policy but also how the policy is doing or not.

Research location is in district langkat province north sumatera with focus at public health office in nutrition community department, and family health department. It also was doing in health center Pantai Cermin as one example health center with stunting toddler. In health center will do in depth interview with head of the health center and village midwife in pematang serai as a village with numbers stunting highest in working area of health center Pantai Cermin and the other informan is from empowering children and women office.

Choose informants use technic non probability sampling with method purposive sampling with criteria of chosen informants suitability and adequacy that is according to the needs and if data is enough and can describe the conditions that need in this research.

This research use consolidated framework for implementation research (CFIR) as a tool to collect all data. The CFIR have five domains and thirty nine constructions to diagnose implementation of the program are done at October 2018.

\section{Result and Discussion}

From indepth interview that was doing to five informans and the result is part into five domain of CFIR, classification, and spesification what factors that influence the implementation program:

Result of this research from all the domain of CFIR there are four domain that have impact those are outer setting, inner setting, characteristic of individual and proccess.

a. From outer setting in patient need informants say they know all the patient need from live review result to community, as the village midwife and head of health center they have some people who register all the need of community with asking personally about their need and hope, then it will make in a paper then it report to head of health center. From datas they will make what program will choose according community need. If the nutrition and family health departemen they doing the same but the program that will do is come from departement of health in Jakarta, they only doing what programs that choose in Jakarta. 
b. Inner setting in tension for change, in head of health center say that people in health center just doing their work as obligation, they work because they were paid, but the program is done as long time before, so they have understood about that program, and it has no difficulty for them to do it in community, and their feeling when doing the program for the first time is not too difficult just need adaptation with community, but it can doing well after some meeting. Same as the village midwife she doing the program because that program come from head of health center so it must done, first she learn about the program and slowly doing in community, first time she feel uncomfort because she not yet understand about that program, but slowly she understand she can doing that easy in community.

The nutrition and family health departement more understand about tension for change, part of the staff understand that they must know what is the goal of the program so that they can understand that there is a need from themselves to change and understand what is spesific and sensitive nutrition intervention is.part of the team just doing their obligation and not too understand about tension of change. But the head of departement nutrition and family health always know them the goal from personal meeting in departemen, in order step by step they understand about it.

c. Inner setting in compatibility about the program spesific and sensitive nutrition intervention are compatibility with customary value and norms in community, the village midwife as the person who immediately connect with community never has some obstacle about norms, it means the program is compatiblewith comunity norms. Same recognition come form head of health center, nutrition departement and family health departement.

d. Inner setting in incentive and reward this program come in the middle of budget, it makes nutrition and family departement cannot make a budget about the incentive people who doing the program of spesific and sensitive nutrition intervention in their departement, but in public health it has budget from BOK fund, although it come in middle of budget, head of health center still can rotate the budget to program spesific and sensitive nutrition intervention. It same with the village midwife because she just doing the program from head of health center.

e. Inner setting in goals and feedback nutrition departement, family health departement, head of health center and village midwife all of them knows that there are goals that made by center of public health in jakarta about the program of spesific and sensitive nutrition intervention in order all part that doing this program can evaluating their performance to do it. The goals also made to see feedback from all departement that do the program, when the performance is evaluating so that they know what feedback need from their performance. They can see what is needed or what is not from the goals and the head of public health office have been made the spesific goals in order all the program can evaluate and give feedback each other.

f. Inner setting in leadership engagement the leader of public health office in kabupaten langkat really concern to finish this condition of stunting esspecially in program that immediatelly take care of stunting that is departemen nutrition and health center. They feel engagemet of leadership immediately because the leader go down in their departement from program spesific and sensitive nutrition intervention. High numbers of stunting in district langkat make full attention of the leader how to finish it. In departemen family health the leader also give attention but not too concern like in the nutrition departement and health center office. But the leader give attentions from follow the general meeting that do everymonth and evaluate every part in family health esspecially program about stunting. 
g. Characteristic of individual in individual stage of change informants in departement of nutrition and family health make this program as a job that must do, it means they must do this job because it is their job. For a week, a month, three months and every semester they must be evaluated for what they do, so they must do it well. As a career responsibility people in departement nutrition and family health must understood all the program spesific and sensitine nutrition intervention, they must be make a evaluation from the program, then make a follow up plan in next semester in order increasing step to do. as the head of health center he said individual stage of change is influenced by how deep we know about the program. In case of stunting head of health center pantai cermin has follow many meeting about program, intervention, technic in field and some result ofintervention of stunting. Head of health center learn more than other because health center is spearhead of service so there are more case happen in health center than in departement. For the village midwife she just doing what must do as a command by the head of health center, just doing what must do.

h. Proccess in internal implemetation leaders and external change agent there is not meaningfull change from this category because the proccess of doing the program in every sector not have significant obstacle. There only one leader in every departement, it means there is no other leader in proccess implementation program. That means also there is not external agent of change, it totally doing by the staff of the public health as state cipil aparatur without intervention from outer of the agency.

\section{Conclusion}

The conclusions of this research are:

a. Outer setting in point patient need all of informants agree that they collect all data patient needs from the community, so it has been acomptable with human needs

b. In inner setting from five constructions tension for change, comptability, incentives and reward, goals and feedback, leadership engagement the goodest construction is in comptability, it means this program is comptability and according to norms in community, and that must repair is in incentives and reward, because this program is happening in the middle of budgeting, there is no budget for incentive, but later it must be in order staff can do the program without obstacle, specially in fund obstacle.

c. Characterictic of individual not have some meaningfull obstacle, most of people just do the job without know that sometimes they must understand why it happens and doing, not only because of job.

d. So the factors that influence spesific and sensitive nutrition intervention are from all the staffs and the factors are how to know patient needs as the job of staff, tension for change by everyone need to increase in order better to work, individual stage of change as a modals for staff in order know not only because job, but must understand esencial of a program.

\section{References}

Arikunto, Suharsimi. (2013). Prosedur Penelitian, Suatu Pendekatan Praktek, Rineka Cipta, Jakarta

Afrizal. (2014). Metode Penelitian Kualitatif, RajaGrafindo Persada, Jakarta

Dunn, William N., (2003). Pengantar Analisis Kebijakan Publik, Gadjah Mada University Press, Yogyakarta 
Damschroder, L. J., \& Lowery, J. C., (2013). Evaluation of a large-scale weight management program using the consolidated framework for implementation research Implementation Science: IS, 8(1), 51. http://doi.org/10.1186/1748-59088-51

Damschroder, L. J., (2012). The Role and Selection of Theoretical Frameworks in Implementation Research. Ann Arbor VA Center for Clinical Management Research .

Forum Nasional Jaringan Kebijakan Kesehatan Indonesia (Fornas JKKI)., (2017). Pembangunan Kesehatan Bersama Jaminan Kesehatan Nasional, Forum Nasional Jaringan Kebijakan Kesehatan Indonesia, Yogyakarta : Kementerian Kesehatan Republik Indonesia.

Hasibuan, S. M. et al. (2020). Relationship of Family Income and Family Support with Maternal Reference in Pregnant Women in Pantai Cermin BEmONC, Langkat District, 2019. Budapest International Research and Critics Institute-Journal (BIRCI-Journal). P. 486-493

Imron, Moch TA., (2014). Metodologi Penelitian Bidang Kesehatan, Sagung Seto, Jakarta

Morse, Janice M., 1992. Qualitative Health Research, SAGE Publications International Educational and Professional Publisher, London

Notoatmodjo, Soekidjo. (2002). Metodologi Penelitian Kesehatan, Rineka Cipta, Jakarta

Nugroho, Riant. (2014). Metode Penelitian Kebijakan, Pustaka Pelajar, Yogyakarta

Nasution, S., (2002), Metode Research (Penelitian Ilmiah), Bumi Aksara, Jakarta

Kemenkes RI., (2011). Keputusan Menteri Kesehatan Republik Indonesia Nomor 1995/MENKES/SK/XII/2010 tentang Standar Antropometri Penilaian Status Gizi Anak, Jakarta : Dirjen Bina Gizi dan Kesehatan Ibu dan Anak Kemenkes RI.

Kemenkes RI., (2015). Rencana Strategis Kementerian Kesehatan Republik Indonesia Tahun 2015-2019, Jakarta : Kementerian Kesehatan Republik Indonesia.

"Mengenal "Stunting" dan Efeknya pada Pertumbuhan Anak", https://lifestyle.kompas.com/read/2017/02/08/100300123/mengenal.stunting.dan.efekny a.pada.pertumbuhan.anak.

Peter, D. H., Tran, N. T., \& Adam, T., (2013). Implementation Research in Health : A practical Guide, Geneva : WHO Switzerland.

Peter, D. H., El-Saharty, S., Siadat, B., Janovsky, K., \& Vujicic, M. (2009). Improving Health Service Delivery in Developing Countries, Washington DC : World Bank Publications. http://doi.org/10.1596/978-0-8213-7888-5

Proctor, E. K., Powell, B. J., \& McMillen, J. C. (2013). Implementation strategies: recommendations for specifying and reporting. Implementation Science : IS, 8, 139. http://doi.org/10.1186/1748-5908-8-139

Riset Kesehatan Dasar (RISKESDAS) (2013) : Badan Penelitian dan Pengembangan Kesehatan Kementerian Kesehatan Republik Indonesia.

Shinta, H.,E. et al. (2020). Potential Stunting in Riverside Peoples (Study on Pahandut Urban Village, Palangka Raya City). Budapest International Research and Critics InstituteJournal (BIRCI-Journal). P. 1618-1625

Surantini, SI., 2015. Profil Kesehatan Provinsi Sumatera Utara Tahun (2014), Medan : Dinas Kesehatan Provinsi Sumatera Utara.

Sutarjo, U.S., Budijanto, Didik., et al, (2017). Profil Kesehatan Indonesia Tahun 2016, Jakarta : Kementerian Kesehatan Indonesia.

Sugiyono. (2005). Memahami Penelitian Kualitatif, Alfabeta, Bandung

Sukidin, Basrowi. (2002), Metode Penelitian Kualitatif Perspektif Mikro, Insan Cendikia, Surabaya 
Tim Nasional Percepatan Penanggulangan Kemiskinan (TNP2K). (2017). 100 Kabupaten/Kota Prioritas untuk Intervensi Anak Kerdil (Stunting) Ringkasan, Tim Nasional Percepatan Penanggulangan Kemiskinan : Sekretariat Wakil Presiden Republik Indonesia.

Trisnantoro, Laksono. (2016a). Mengapa Riset Implementasi Diperlukan, Yogyakarta : Pusat Kebijakan Dan Manajemen Kesehatan Universitas Gadjah Mada.

Trisnantoro, Laksono. (2016c). Apa Itu Riset Implementasi, Yogyakarta : Pusat Kebijakan Dan Manajemen Kesehatan Universitas Gadjah Mada.

Team, C. R., Research, C. for C. M., \& Complex, N. C. R. (n.d.). Consolidated Framework for Implementation Research. Retrieved from http://cfirguide.org/constructs.html

WHO. (2014). Implementation Research Toolkit. Geneva Switzerland: WHO.

WHO. (2014). Implementation Research in Health - A Practical Guide Chapter 1-4. Geneva Switzerland: WHO 